\title{
Exploring Small Group Analysis of Instructional Design Cases in Online Learning Environments
}

\author{
Jesus Trespalacios \\ Boise State University
}

\begin{abstract}
The case-based approach is a constructivist instructional strategy that helps students apply their emerging knowledge by studying design problems in authentic real-world situations. One important instructional strategy in case-based instruction is to analyze cases in small groups before discussing them with the whole class. This study investigates the use of small-group structure to analyze case studies in online learning environments, as well as students' perceptions of the use of VoiceThread presentations to improve their learning of instructional design. The results show that a small group strategy has great potential to help students analyze case studies and consequently enhance learning. The implications of these findings for instructional designers and online instructors are discussed.
\end{abstract}

Keywords: Instructional Design; Case Studies; Online Learning; VoiceThread

Trespalacios, J. (2017). Exploring small group analysis of instructional design cases in online learning environments, Online Learning 21(1) 189-200. doi: 10.24059/ olj.v21i1.928

\section{Introduction}

Case-based approaches are constructivist instructional strategies that help students apply their emerging knowledge by studying design problems in authentic real-world situations (Jonassen, 1999, 2011; Jonassen \& Hernandez-Serrano, 2002; Stepich \& Ertmer, 2009). Research has shown that this approach is an effective strategy used to teach medicine, business, law, psychology, and teacher preparation (Lee et al., 2009; Pena-Shaff \& Altman, 2009; Saleewong, Suwannatthachote \& Kuhakran, 2012). For example, Honan and Rule (2002), Barnes, Christensen, and Hansen (1994) and Argyris (1980) agreed that real problems, analysis, and active student involvement are the central elements of case method teaching and learning. In the teaching of instructional design (ID), Carr-Chellman (1999) described this strategy as relevant because this field focuses essentially on solving ill-structured problems that possess incomplete information and multiple solutions. Additionally, Julian, Kinzie, and Larsen (2000) stated, 
In case analysis, instructional design students draw connections between their emerging knowledge of ID and the complex demands of actual practice. Cases can supplement student design projects, allowing further opportunity to reflect on relevant theory and methods as students explore a greater number of design issues in a broader array of environments (p. 165).

Wasserman (1994) described four necessary components in case-based instruction: (1) a case report, (2) study questions, (3) small group work, and (4) a whole group discussion. Considering cases as problems to solve, Jonassen (2011) also recommended the following four steps to support students' problem-based learning (PBL): (1) small group discussions to reason through the problem, (2) individual analysis of the case to understand the problem and find possible solutions, (3) students share what they have learned with the group and revisit the problem, and (4) "[a]t the end of the learning period (usually one week), students summarize and integrate their learning” (p. 154).

\section{Instructional Design Expertise}

One of the goals in instructional design courses is to provide students with opportunities to develop problem-solving skills to deal with instructional design situations where they need to identify issues and suggest instructional solutions (Ertmer \& Stepich, 2005). However, developing this expertise in novice instructional designers is not an easy task because of the illstructured nature of instructional design problems (Jonassen, 2011). Investigating the impact of guidance on the development of expertise by novice instructional designers, Ertmer et al. (2009) found that novices were able to perform more like instructional design experts after using the following analysis guidelines: (a) use your own words, (b) focus on the big picture rather than surface details, (c) make assumptions about missing information, (d) focus on root causes rather than quick fixes, (e) consider the core issues (those that are most central to your understanding of the situation), (f) consider the critical issues (those that are likely to have the greatest impact on a successful resolution), (g) if you identify multiple issues, think about how those issues fit together, and (h) think about where the issues you identify fit within the instructional design model. In fact, Ertmer et al. (2009) suggested, "the guidance encouraged novices to synthesize rather than summarize information, focus on principles rather than on surface features, identify relationships among identified issues, and make assumptions (i.e., to be reflective) based on what was stated in the case” (p. 121).

\section{Small Group Activities in Online Environments}

Research has shown that the process of peers working together in small groups appears to produce positive academic outcomes (Blumenfeld, Marx, Soloway \& Krajcik, 1996; Wentzel \& Watkins, 2011). More specifically, in a seminal work on the use of case studies to enhance instructional design education, Ertmer and Russell (1995) discussed the relevance of small group work:

Following the case presentation, students work individually or in groups to analyze the data, evaluate the nature of the problem(s), decide upon applicable principles, and recommend a solution or course of action. Small group work, in or out of class, gives students the opportunity to discuss cases and questions with each other prior to the whole 
class discussion. These sessions give students their first chance to examine the issues presented in the case study; ideas are tried out in the safest of contexts. Study groups engage students in thoughtful consideration of the case issues and primes them for the more demanding whole-class discussion that follows (p. 24).

Thus, the creation of small groups to discuss cases is a relevant instructional activity that allows students to interact and identify key points before participating in the class discussion (Flynn \& Klein, 2001).

After analyzing group-solving styles in two asynchronous online courses, Lowes (2014) recommended the following strategies to design collaborative group projects: (1) require a unique contribution from each group member; (2) provide clear instructions about collaborative activities; and (3) make available spaces for collaboration among the group members. One alternative to provide a space for students is to integrate computer-mediated communication (CMC) tools that allow students to communicate asynchronously and provide this important interaction among students (Benbunan-Fich \& Hiltz, 1999; Rourke \& Anderson, 2002). Recent studies have shown the relevance of video communication using tools such as VoiceThread to support communication and social presence among students in distance environments (Borup, West \& Graham, 2013; Ching \& Hsu, 2013). Thus, the purpose of this study was to explore the effectiveness of small group analysis of instructional design cases and students' perceptions of this activity in online learning. The research questions that guided this exploratory study were as follows: In an online learning environment,

RQ1: How effective is the small group analysis of cases in instructional design when compared with experts' analysis?

RQ2: What are students' perceptions of case-based VoiceThread presentations with regard to improving their learning of instructional design?

\section{Methods}

Twenty-one students enrolled in an online course in ID participated in this study. This three-credit course is required for the master's degree program in Educational Technology. Based on participants' introductions at the beginning of the course, students had a broad range of backgrounds, knowledge, and experiences. At the time of taking this course, five of the participants were technology coordinators or coaches for different schools, fifteen were teachers (elementary and secondary), and one worked for a consulting firm as an instructional designer. Thirteen participants were female (62\%) and eight were male (38\%). Eighteen participants lived in the United Stated and three lived overseas.

\section{Course Setting}

One week before the start of the course the participants received detailed information about the course objectives and activities and became familiar with the learning management system (LMS) Moodle in which the course was implemented. The content of the course was divided into weeks, starting on Mondays and ending at midnight on Sundays. This 15-week course contained different activities such as creating an ID job description, leading and participating in discussion forums, producing an instructional design project, and creating 
VoiceThead presentations. During the first week, students were asked to briefly introduce themselves using VoiceThread.

The main readings of the course are from two textbooks. Streamlined ID (Larson \& Lockee, 2014) is the ID textbook that the class follows to discuss introductory concepts in the field. The second textbook is the ID casebook written by Ertmer, Quinn and Glazewski (2014a), which is divided into three different sections. The first section contains 7 cases situated in K-12 environments, the second section contains 11 post-secondary cases, and the final section includes 12 cases situated in a corporate or manufacturing environment. Cases are approximately 4-7 pages long including text and pictorial material, and each one of them contains questions for preliminary analysis and implications for ID practice that could help instructors to organize their case-based instruction. As defined by the authors,

The cases in this book are designed to be dilemma oriented: each case ends before the solution is clear. Students are expected to evaluate available evidence, to make reasonable assumptions as necessary, to judge alternative interpretations and actions, and, in doing so, to experience the uncertainty that commonly accompanies design decisions. (Ertmer et al., 2014a, p. xiv)

\section{Small Group Activity}

Following Wasserman (1994) and Jonassen's (2011) recommendations, students were randomly assigned to one of the five groups during the second week of the course. Each group was required to analyze three ID case studies (one for each level: K-12, higher education, and business) and lead a whole-class discussion. Members of the small groups were required to create a VoiceThread presentation where they analyzed the cases discussing the main issues and possible solutions. Requiring analysis of one main issue per slide, VoiceThread presentations contained 9 to 12 slides in total with audio comments ranging from 2 to 4 minutes per slide. All group members were required to participate in the presentation. Group members were encouraged to work on a Google presentation to create the slides, ensuring that the same format (background, font, and layout) would be used on each slide. Finally, five weeklong discussions were designed to discuss the cases with the whole class. VoiceThread presentations were shared at the beginning of each week to support the whole-class discussions that were led by the members of the small group.

Cases from the ID casebook (Ertmer, et al., 2014a) were chosen based on the relationship they had with the content of the ID textbook (Larson \& Lockee, 2014). For instance, initial cases were related to task analysis or needs assessment because the analysis component of the instructional design process was discussed in the first chapters of the ID textbook (see Table 1). This decision was made based on the recommendation that "instruction created to help novices think like experts must be matched to the learners' existing knowledge and understanding, to make the tools of expertise accessible to them.” (Hardré, Ge, \& Thomas, 2006, p. 65). Additionally, the checklist developed by Ertmer et al. (2009) was provided to support the small group discussion and the individual analysis of the cases as experts. 
Table 1

Discussions Content and Organization

\begin{tabular}{|c|c|c|c|}
\hline Groups & $\begin{array}{l}\text { Weeks in the } \\
\text { semester }\end{array}$ & $\begin{array}{l}\text { Cases assigned from the } \\
\text { ID casebook }\end{array}$ & $\begin{array}{l}\text { ID Content assigned from } \\
\text { textbook }\end{array}$ \\
\hline $\begin{array}{l}\text { Group } 1 \\
(\mathrm{n}=4)\end{array}$ & Week 4 & Cases 7, 18 and 28. & $\begin{array}{l}\text { Analyzing needs and learners } \\
\text { (chapters } 1-3 \text { ) }\end{array}$ \\
\hline $\begin{array}{l}\text { Group } 2 \\
(\mathrm{n}=4)\end{array}$ & Week 5 & Cases 6, 10 and 19. & $\begin{array}{l}\text { Analyzing context and content } \\
\text { (chapters 4-5) }\end{array}$ \\
\hline $\begin{array}{l}\text { Group } 3 \\
(\mathrm{n}=4)\end{array}$ & Week 9 & Cases 3, 8, and 29. & $\begin{array}{l}\text { Aligning instruction and } \\
\text { assessing learning (chapters 6-7) }\end{array}$ \\
\hline $\begin{array}{l}\text { Group } 4 \\
(n=4)\end{array}$ & Week 10 & Cases 2, 9 and 20. & $\begin{array}{l}\text { Selecting strategies and } \\
\text { technologies } \\
\text { (chapters 8-9) }\end{array}$ \\
\hline $\begin{array}{l}\text { Group } 5 \\
(\mathrm{n}=5)\end{array}$ & Week 13 & Cases 1,13 and 21. & $\begin{array}{l}\text { Producing and implementing } \\
\text { instruction (chapters 10-11) }\end{array}$ \\
\hline
\end{tabular}

\section{Data Collection and Analysis}

To answer the first research question, (RQ1: How effective is the small group analysis of cases in instructional design when compared with experts' analysis?) VoiceThread presentations from the five small groups were analyzed using content analysis. As stated by Hsieh and Shannon (2005), "qualitative content analysis is defined as a research method for the subjective interpretation of the content of text data through the systematic classification process of coding and identifying themes or patterns” (p. 1278). To ensure consistency and comparability among the messages provided on VoiceThread, the information presented on each slide was treated as the unit of analysis. Using this strategy, 49 entries of information were identified for analysis. To establish validity in the content analysis process (Potter \& Levine-Donnerstein, 1999; Rourke \& Anderson, 2004), the instructor's resource manual for the ID casebook (Ertmer, Quinn \& Glazewski, 2014b) was used to design the coding scheme. Thus, the data analysis process began with an identification of the main problems/issues that students found in their analysis of the instructional design cases across the written text and the audio presentation in each slide of the VoiceThread presentations. Then, these issues were compared with the issues identified by experts presented in the instructors' ID Casebook manual for each case. Besides analyzing the presence of experts' issues in the small group analysis of ID cases, a rubric with three levels was created to grade the level of similarity between the issues identified for the small groups and the experts. Three points were given if the issue described by the group matches completely to one of the issues discussed in the instructor's manual, two points if the issue was strongly related, one point if the issue is slightly related, and zero points if the issue was not described in the manual. It is important to note that because cases were chosen based on the relationship they have with the content of the ID textbook, initial small groups had less content knowledge and experiences as a reference than later groups. Thus, there is no intention to compare the performance between groups or evaluate who did better in the analysis of the ID cases. 
Table 2

Examples of the Coding Scheme for the Type of Issues Identified

\begin{tabular}{|c|c|c|c|}
\hline $\begin{array}{l}\text { ID Case } \\
\text { Studies }\end{array}$ & $\begin{array}{l}\text { Issues Identified } \\
\text { by Experts }\end{array}$ & Issues Identified by Students & Points \\
\hline $\begin{array}{l}\text { Case } 7 . \\
\text { Implementing } \\
\text { New } \\
\text { Instructional } \\
\text { Approaches in } \\
\text { a K-12 Setting }\end{array}$ & $\begin{array}{l}\text { - Needs } \\
\text { assessment } \\
\text { - Change } \\
\text { management } \\
\text { - Instructional } \\
\text { strategies }\end{array}$ & $\begin{array}{l}\text { - Needs analysis: Not all stakeholders were } \\
\text { interviewed. Not all needs were verified and } \\
\text { supported by data. } \\
\text { - Context analysis: Community's resistance to } \\
\text { education was acknowledged but investigated or } \\
\text { addressed } \\
\text { - Theoretical context: Learning context does not } \\
\text { adequately consider performance context but Ruth } \\
\text { Ann is resistant to change her teaching style }\end{array}$ & 2 \\
\hline $\begin{array}{l}\text { Case 18. } \\
\text { Designing } \\
\text { Curriculum } \\
\text { for Southeast } \\
\text { Asian Trainers }\end{array}$ & $\begin{array}{l}\text { - Instructional } \\
\text { strategies } \\
\text { - Learner/cultural } \\
\text { analysis } \\
\text { - Assessment }\end{array}$ & $\begin{array}{l}\text { - Theoretical Context: Singaporean trainers prefer } \\
\text { instructivist approach while the US trainers prefer } \\
\text { constructivist/connectivist } \\
\text { - Cultural Context: The Singaporean culture was not } \\
\text { fully researched before interviews with the trainers } \\
\text { therefore the US instructional designers were unable } \\
\text { to collect stakeholders (Singaporean trainer) } \\
\text { expectations } \\
\text { - Learner Analysis: An inadequate learner analysis } \\
\text { resulted in unmotivated Singaporean learners }\end{array}$ & 3 \\
\hline $\begin{array}{l}\text { Case } 28 . \\
\text { Managing } \\
\text { Training in a } \\
\text { Manufacturing } \\
\text { Setting }\end{array}$ & $\begin{array}{l}\text { - Managing } \\
\text { company-wide } \\
\text { training } \\
\text { - Learner analysis } \\
\text { - Needs } \\
\text { assessment } \\
\text { - } \\
\text { Diversity/language } \\
\text { needs }\end{array}$ & $\begin{array}{l}\text { - Learner Analysis: Language barriers impact how } \\
\text { training is completed and how target audience achieve } \\
\text { necessary certifications. } \\
\text { - Needs Analysis: Too many employees receiving } \\
\text { training causing a shortage of people performing their } \\
\text { assigned jobs. } \\
\text { - Learner \& Performance Context: There are no } \\
\text { guidelines for implementing peer to peer training. } \\
\text { Technicians do not have equal opportunities for } \\
\text { training. } \\
\text { - Context Analysis: The theoretical context between } \\
\text { peer trainers varies on how they assess trainee } \\
\text { learning. }\end{array}$ & 3 \\
\hline
\end{tabular}

To answer the second question (RQ2: What are students' perceptions of case-based VoiceThread presentations with regard to improving their learning of instructional design?) one open-ended question and three five-point Likert scale questions (1=Strongly disagree; $5=$ Strongly agree) related to this activity were added to the course evaluation survey:

1. How have case-based analysis and discussions played a role in your overall learning experience? (open ended question)

2. Creating a VoiceThread presentation with my group improved my understanding of the case(s) assigned. 
3. VoiceThread presentations supported my understanding of all three cases assigned each week.

4. VoiceThread presentations helped me analyze the cases discussed in the Moodle forums.

Answers to the open-ended questions were analyzed using inductive coding (Miles, Huberman, \& Saldaña, 2014). As defined by Thomas (2006), "inductive analysis refers to approaches that primarily use detailed readings of raw data to derive concepts, themes, or a model through interpretations made from the raw data by an evaluator or researcher.” (p. 238).

\section{Results and Discussion}

Using the coding scheme presented in Appendix A, 49 entries (issues) presented by the small groups were analyzed. Table 3 presents the descriptive data showing the detailed breakdown of the scores for each of the five groups on each one of the categories of the ID cases. The average score for each presentation was approximately 2 points out of 3 . The results of the content analysis showed that, on average, the issues identified for the small group members in each of the three case studies were "strongly similar" to the main issues identified by the authors of the ID casebook. The results support the notion that creating a small group discussion and requiring students to develop a VoiceThread presentation following scaffolding guidelines to analyze ID case studies helped students find relevant issues about the cases. As discussed by Kim and Hannafin (2008), peer collaboration in case-based activity helps individuals to generate and share ideas, and practice articulating those ideas.

Table 3

Scores for Each ID Case Category

\begin{tabular}{ccccc}
\hline Groups & K-12 & $\begin{array}{c}\text { Higher } \\
\text { Education }\end{array}$ & Business & Average points \\
\hline Group 1 $(\mathrm{n}=4)$ & 2.3 & 2.6 & 1.5 & 2.1 \\
Group 2 $(\mathrm{n}=4)$ & 1.3 & 2.0 & 2.6 & 2.0 \\
Group 3 $(\mathrm{n}=4)$ & 1.3 & 2.3 & 1.3 & 1.7 \\
Group 4 $(\mathrm{n}=4)$ & 2.0 & 2.5 & 2.3 & 2.3 \\
Group 5 $(\mathrm{n}=5)$ & 1.3 & 1.3 & 2.3 & 1.6 \\
Total & 1.64 & 2.08 & 2.10 & 1.95 \\
\hline
\end{tabular}

$0=$ Issue identified is different; $3=$ Issue identified is the same

Answers from the Likert-scale questions about the use of VoiceThread presentations (Table 4) showed the relevance of watching small group presentations before the whole-group discussion. Students agreed that the presentations helped them to better understand the three cases assigned each week and to analyze the case assigned in the Moodle discussion forums more effectively. Additionally, students agreed that developing a VoiceThread presentation with the group improved their understanding of the assigned cases. These results confirmed the findings in the literature that learning and knowledge building in PBL environments is a collaborative experience (Hmelo-Silver \& DeSimon, 2013). 
Table 4

Students’ Perceptions of Small-Group VoiceThread Presentations

\begin{tabular}{lc}
\hline \multicolumn{1}{c}{ Question } & $M(\mathrm{n}=18)$ \\
\hline $\begin{array}{l}\text { VoiceThread presentations supported my understanding of the cases } \\
\text { assigned each week. }\end{array}$ & 4.22 \\
$\begin{array}{l}\text { VoiceThread presentations helped me analyze the case assigned in the } \\
\text { discussion forums more effectively. }\end{array}$ & 4.11 \\
$\begin{array}{l}\text { Creating a VoiceThread presentation with my group improved my } \\
\text { understanding of the case(s) assigned. }\end{array}$ & 4.17 \\
\hline 1=Strongly disagree; 5=Strongly agree
\end{tabular}

Finally, 13 students' responses to the open-ended question on how case-based analysis and discussions played a role in their overall learning experience were inductively analyzed to determine common patterns or central themes. Most of the respondents indicated a positive view of the relevance of this activity in their instructional design learning as discussed by CarrChellman (1999). The most prevalent theme was the helpfulness of the instructional activity. The following students' opinions are some examples that illustrate this aspect. One student said, "The case-based analysis and discussions helped me understand the concepts better. I was able to listen to and read everyone else's interpretations and it helped me see different points of view." Another student said, "Definitely. They really helped me feel like I could step into the role of being an ID. The readings and discussions were extremely beneficial!” In addition, a student reported, "The case-based analysis and discussions were great! I thoroughly enjoyed the forum discussions. I felt that the VT [VoiceThread] presentations helped when I watched them before and after reading the cases. Overall, I like VT, but I felt that I learned a lot more from the forum discussions.”

The use of case studies as real examples was another common theme raised by students that demonstrated the strength of this activity. As one student expressed, "Having real world examples to dissect was very helpful. Also, it was interesting to see how different students interpreted the problem and solution to various cases. It was like having a large think tank." Another student pointed out the variety of cases, stating that "They provided real-world examples in multiple areas; i.e. K-12, Higher Ed, and Industry.” Finally, a few respondents reported that other activities were more relevant to their learning experience. One student thought the VoiceThread presentations were "Not as helpful as the actual project." Another student reported, "Overall, I like VT [VoiceThread], but I felt that I learned a lot more from the forum discussions.”

\section{Recommendations}

Based on the results of this study and the experiences designing small group discussions on case-based instruction, several recommendations can be offered. First, implementing a small group discussion of a specific case study prior to the whole-class discussion can be an effective instructional strategy in online learning environments. In this study, members of the small groups were also the leaders of the whole-class online discussion forums. Since students in the small group analyzed the cases together previously, they could offer stronger feedback to their classmates during discussions. Second, as concluded by Lowes (2014), requiring unique 
contributions for each group member is key to the relevance of the small group work. Asking that each student present some analysis of the cases in VoiceThread was necessary to collect the points of view of different students as well as promote active participation of all students in the groups.

In addition, the integration of a Google presentation and VoiceThread as available spaces for collaboration among the group members facilitated the asynchronous communication among students. The small groups' VoiceThread presentations were posted for the whole class to view, increasing the potential learning benefits that come from student content creation and sharing (Bennett, Bishop, Delgarno, Waycott, \& Kennedy, 2012). Finally, although it was not implemented in this study, a synchronous meeting of the instructor with members of the small group prior to the creation of the VoiceThread presentation is recommended. In this study, the examination of the presentations shows an acceptable level of analysis; however, low levels of critical thinking on some of the issues presented by the students were also present. An initial synchronous conversation with the small group about the case studies following the guidelines provided by Ertmer et al. (2009) could help students to provide stronger arguments about the issues and possible solutions to the different case studies.

\section{Conclusions}

Case-based instruction is an important strategy that has been widely utilized in areas such as law, medicine, nursing, and teacher education. The use of this strategy in distance education is important for developing students' critical thinking and problem solving skills in addition to improving communication and collaboration skills (Pena-Shaff \& Altman, 2009; Rourke \& Anderson, 2002). This study aimed to contribute to the online learning research and practice through exploring the design of PBL environments using case-based scenarios, as well as learners' perceptions of small group presentations to promote learning. This investigation also explored the formation of small groups to analyze instructional design cases and develop VoiceThread presentations that summarized the issues and possible solutions to three assigned cases.

Results supported previous findings that small group activities centered around case studies can enhance student learning. Specifically, our research confirmed that the small group activity involving the presentation of the case studies' analyses before the whole group discussion is a relevant strategy in distance learning environments. For educators in the field of instructional design, this research contributes to the literature by presenting an example of how small group discussions using VoiceThread provide PBL experiences in an online environment.

Finally, a limitation of this study is that data was not collected on participants' interaction in these small groups. Since the level of students' interaction in small groups is related to increased understanding (Webb, 1989), future studies with a similar design are encouraged to observe the interactions among the members of the groups and confirm the collaborative experience in the PBL online environment. In addition, results from this study need to be interpreted with caution due to the small number of participants and the specific learning context (i.e., adult learners in an online learning environment). Additional research with different types 
of students (K-12 and/or undergraduate) and different content knowledge is recommended to confirm these results.

\section{References}

Argyris, C. (1980). Some limitations of the case method: Experiences in a management development program. Academy of Management Review, 5(2), 291-298.

Barnes, L. B., Christensen, C. R., \& Hansen, A. J. (1994). Teaching and the case method: Text, cases, and readings (3rd ed.) Boston, MA: Harvard Business School Press.

Benbunan-Fich, R., \& Hiltz, S. R. (1999). Educational applications of CMCS: Solving case studies through asynchronous learning networks. Journal of Computer-Mediated Communication, 4(3). Retrieved from http://onlinelibrary.wiley.com/doi/10.1111/j.10836101.1999.tb00098.x/full

Bennett, S., Bishop, A., Delgarno, B., Waycott, J., \& Kennedy, G. (2012). Implementing web 2.0 technologies in higher education: A collective case study. Computers and Education, 59, 524-534.

Blumenfeld, P. C., Marx, R. W., Soloway, E., \& Krajcik, J. (1996). Learning with peers: From small group cooperation to collaborative communities. Educational Researcher, 25(8), $37-40$

Borup, J., West, R. E., \& Graham, C. R. (2013). The influence of asynchronous video communication on learner social presence: A narrative analysis of four cases. Distance Education. 34, 48-63.

Carr-Chellman, A. A. (1999). I have a problem! The use of cases in educating instructional designers. TechTrends, 43(6), 15-19.

Ching, Y.-H., \& Hsu, Y.-C. (2013). Collaborative learning using VoiceThread in an online graduate course. Knowledge Management \& ELearning, 5(3), 298-314.

Ertmer, P. A., Quinn, J. \& Glazewski, K. D. (2014a). The ID casebook: Case studies in instructional design (4th ed.). Upper Saddle River, NJ: Pearson.

Ertmer, P. A., Quinn, J. \& Glazewski, K. D. (2014b). Instructor's resource manual for the ID casebook: Case studies in instructional design (4th ed.). Upper Saddle River, NJ: Pearson.

Ertmer, P. A. \& Russell, J. D. (1995). Using case studies to enhance instructional design education. Educational Technology, 35(4), 23-31.

Ertmer, P. A., \& Stepich, D. A. (2005). Instructional design expertise: How will we know it when we see it? Educational Technology, 45(6), 38-43. 
Ertmer, P. A., Stepich, D. A., Flanagan, S., Kocaman-Karoglu A., Reiner, C., Reyes, L., Santone, A. L. \& Ushigusa, S. (2009). Impact of guidance on the problem-solving efforts of instructional design novices. Performance Improvement Quarterly, 21(4), 117-132.

Flynn, A. E., \& Klein, J. D. (2001). The influence of discussion groups in a case-based learning environment. Educational Technology Research and Development, 49(3), 71-86.

Hardré, P. L., Ge, X., \& Thomas, M. K. (2006). An investigation of development toward instructional design expertise. Performance Improvement Quarterly, 19(4), 63-90.

Hmelo-Silver, C. E., \& DeSimone, C. (2013). Problem-based learning: An instructional model of collaborative learning. In C. E. Hmelo-Silver, C. A. Chinn, C. K. Chan, \& A. O’Donnell (Eds.), The international handbook of collaborative learning (pp. 370-385). New York, NY: Routledge.

Honan, J. P., \& Rule, C. S. (2002) Using cases in higher education: A Guide for faculty and administrators. San Francisco, CA: Jossey-Bass.

Hsieh, H-F., \& Shannon, S. E. (2005). Three approaches to qualitative content analysis. Qualitative Health Research, 15(9), 1277-1288.

Jonassen, D. H. (2011). Learning to solve problems: A handbook for designing problem-solving learning environments. New York, NY: Routledge.

Jonassen, D. H. (1999). Designing constructivist learning environments. In C. M. Reigeluth (Ed.), Instructional-design theories and models (2nd ed.) (pp. 215-239). Mahwah, NJ: Lawrence Erlbaum.

Jonassen, D. H. \& Hernandez-Serrano, J. (2002). Case-based reasoning and instructional design: Using theories to support problem solving. Educational Technology Research and Development, 50(2), 65-77.

Kim, H. \& Hannafin, M.J. (2008). Grounded design of web-enhanced case-based activity. Educational Technology Research and Development, 56(2), 161-79.

Larson, M. B., \& Lockee, B. B. (2014). Streamlined ID: A practical guide to instructional design. New York, NY: Routledge.

Lee, S.-H., Lee, J., Liu, X., Bonk, C. J., \& Magjuka, R. J. (2009). A review of case-based learning practices in an online MBA program: A program-level case study. Educational Technology \& Society, 12(3), 178-190.

Lowes, S. (2014). How much "group” is there in online group work? Online Learning Journal, 18(1). Retrieved from http://olj.onlinelearningconsortium.org/index.php/olj/article/view/373/82 
Miles, M. B., Huberman, A. M., \& Saldaña, J. (2014). Qualitative data analysis. A methods source. ( $3^{\text {rd }}$ Ed.). Thousand Oaks, CA: SAGE.

Pena-Shaff, J. B., \& Altman, W. S. (2009). Case-based instruction using asynchronous online discussions: A synthesis. Journal on Excellence in College Teaching, 20(3), 97-121.

Potter, W. J., \& Levine-Donnerstein, D. (1999). Rethinking validity and reliability in content analysis. Journal of Applied Communication Research, 27, 258-284.

Rourke, L., \& Anderson, T. (2004). Validity in quantitative content analysis. Educational Technology Research and Development, 52(1), 5-18.

Rourke, L., \& Anderson, T. (2002). Using web-based, group communication systems to support case study learning at a distance. International Review of Research in Open and Distance Learning, 3(2), 1-13.

Saleewong, D., Suwannatthachote, P. \& Kuhakran, S. (2012). Case-based learning on Web in higher education: A Review of empirical research. Creative Education, 3, 31-34.

Stepich, D. A., \& Ertmer, P. A. (2009). Teaching instructional design expertise: Strategies to support students’ problem-finding skills. Technology, Instruction, Cognition, and Learning, 7, 147-170.

Thomas, D. R. (2006). A general inductive approach for analyzing qualitative evaluation data. American Journal of Evaluation, 27(2), 237-246.

Wasserman, S. (1994). Introduction to case method teaching: A guide to the galaxy. New York, NY: Teachers College Press.

Webb, N. M. (1989). Peer interaction and learning in small groups. International Journal of Educational Research, 13(1), 21-39.

Wentzel, K. R., \& Watkins, D. E. (2011). Instruction based on peer interactions. In R. E. Mayer \& P. A. Alexander (Eds.), Handbook of research on learning and instruction (pp. 322343). New York, NY: Routledge. 